\title{
Soil carbon stock and humification in pastures under different levels of intensification
}

\section{in Brazil}

\author{
Aline Segnini ${ }^{\circledR}$, Alfredo Augusto Pereira Xavier ${ }^{\circledR}$, Pedro Luis Otaviani-Junior ${ }^{1}$, Patrícia Perondi Anchão Oliveira ${ }^{2}$, André de Faria \\ Pedroso ${ }^{(-\infty}$, Maria Fernanda Ferreira Menegucci Praes ${ }^{3(0)}$, Paulo Henrique Mazza Rodrigues ${ }^{3}$, Débora Marcondes Bastos Pereira \\ Milori ${ }^{1 *(1)}$
}

\begin{abstract}
'Embrapa Instrumentação, R. XV de Novembro, 1452 13560-970 - São Carlos, SP - Brasil.

2Embrapa Pecuária Sudeste, Rod. Washington Luiz, km 234, s/n -13560-970 - São Carlos, SP - Brasil.

UUniversidade de São Paulo/FMVZ - Depto. de Nutrição e Produção Animal, Av. Duque de Caxias Norte, 225 - 13635900 - Pirassununga, SP - Brasil.

*Corresponding author <debora.milori@embrapa.br>
\end{abstract}

Edited by: Eduardo Alvarez Santos

Received April 11, 2017

Accepted September 07, 2017

\begin{abstract}
Intensive management of tropical pastures has shown potential for greenhouse gas (GHG) mitigation due to high forage production and $\mathrm{C}$ accumulation in the soil. This study aimed to evaluate different pasture management options in relation to their effect on soil $\mathrm{C}$ stocks and soil organic matter (SOM) humification. Pastures in four beef cattle production systems were assessed: intensive and irrigated pasture with high stocking rate (IHS); dryland pasture with high stocking rate (DHS); dryland pasture with moderate stocking rate (DMS); degraded pasture (DP). The soil under the native forest was also evaluated and soil carbon stocks from the 0-100 and 0-30 cm layers were assessed. Carbon stocks $(0-100 \mathrm{~cm})$ ranged from 99.88 to $142.33 \mathrm{Mg}$ ha $^{-1}$ in DP and DMS, respectively and were, respectively, $14 \%$ and $24 \%$ higher compared to the soil under the forest and indicate the capacity of adequately managed tropical pastures to mitigate GHG emissions from livestock production. Humification indexes indicated the presence of more labile $\mathrm{C}$ in pastures with greater $\mathrm{C}$ accumulation (DHS and DMS), mainly in the upper soil layers, indicating recent $\mathrm{C}$ accumulation resulting from correct management. However, more labile $\mathrm{C}$ can be easily lost to the atmosphere as $\mathrm{CO}_{2}$, depending on pasture management. Low $\mathrm{C}$ stocks associated with high humification indexes are characteristics of DP in which significant amounts of SOM are lost. It is necessary to develop technologies to improve $C$ sequestration in IHS and results indicate the importance of quantifying $C$ stocks in association with $C$ stability. Keywords: Atlantic Forest biome, Brazilian livestock systems, Laser-Induced Fluorescence Spectroscopy, humification index, organic matter
\end{abstract}

\section{Introduction}

The Brazilian government has committed to implementing policies to reduce GHG emissions in the livestock-raising sector by 2020 (Nepstad et al., 2009). Intensive management of tropical grasses has shown GHG mitigation potential as a consequence of the high productivity of these pastures when fertilized, which results in soil carbon (C) accumulation (Oliveira et al., 2007a; Ontl and Schulte, 2012; Bustamante et al., 2012; Ruviaro et al., 2014). Moreover, adequate physiological management of tropical grasses (Conant et al., 2001) and maintenance of soil fertility are agronomic practices that are essential to restore and intensify degraded pastures /Oliveira et al., 2003; Oliveira et al., 2005; Santos and Corrêa, 2005; Oliveira et al., 2008).

Determination of $\mathrm{C}$ content is imperative to any evaluation of the impact of pasture management on soils. According to Braz et al. (2013), well-managed pastures can increase soil C stocks while soils under poorly managed or degraded pastures may lose $\mathrm{C}$ compared to soils under the original vegetation. Studies of $\mathrm{C}$ spatial variability at a depth of $1 \mathrm{~m}$ have shown deep C incorporation in pastures under adequate management (Fisher et al., 1994; Boddey et al., 2010). Grass species with abundant root systems during pasture recovery and intensification processes appear to be the reason for this behavior (Oliveira et al., 2007b).
Irrigation is another factor which must be evaluated in relation to soil $\mathrm{C}$ dynamics. The soil type, crop and soil preparation method are among the factors that may modify the irrigation effect on soil C stocks (Bayer et al., 2006). The increase in soil water content caused by irrigation provides favorable conditions for microbial activity, intensifying microbial organic matter (OM) decomposition and carbon mineralization (Andrén et al., 1992). Although the responses of crops to water supplementation are well known, information on the effects of irrigation on soil organic matter (SOM) and C stocks in tropical warm areas is scarce.

The potential of pastures to retain $\mathrm{C}$ involving OM stability is an important aspect in the identification of GHG mitigation alternatives for the cattle-raising sector in Brazil. However, few studies have evaluated the mitigation potential of pastures by increasing $\mathrm{C}$ sequestration in livestock production systems in the Atlantic Forest biome (Boddey et al., 2006; Assad et al., 2013).

The principal aim of this study was to evaluate the effects of degradation, recovery and intensification of pastures of beef cattle production systems on soil C stocks and SOM humification in the Atlantic Forest biome. In order to evaluate the potential for $\mathrm{C}$ sequestration in deeper layers in the soil a comparative study of C stocks in the $0-30$ and $0-100 \mathrm{~cm}$ soil layers was conducted. 


\section{Materials and Methods}

Study area and soil sampling

The study was carried out in São Carlos, in the state of Sao Paulo, Brazil $\left(22^{\circ} 1^{\prime} \mathrm{S}\right.$ and $47^{\circ} 53^{\prime} \mathrm{W}, 853$ $\mathrm{m}$ above sea level). The experimental period was from 1996 to 2011. The prevailing climate is Cwa, according to the Koeppen classification, with a mean annual temperature of $20^{\circ} \mathrm{C}$ and an average cumulative annual rainfall of around $1,360 \mathrm{~mm}$.

Soil samples were collected in pastures and from the original vegetation (Atlantic Forest - "seasonal semideciduous forest") in a transition zone with two soil types: Hapludox soils (Red Latosol and Yellow Latosol, both Oxisols according to the FAO classification system). Pastures, with two replicates per system (blocks), were subject to four beef cattle production systems, described as follows: intensively managed and irrigated Megathyrsus (Panicum) maximum Jacques (cv. Tanzânia) pasture with a high stocking rate (IHS); intensively managed dryland Megathyrsus (Panicum) maximum Jacques (cv. Tanzânia) pasture with high stocking rate (DHS); dryland pasture with a mix of Urochloa (Brachiaria) decumbens Stapf (cv. Basilisk) and Urochloa (Brachiaria) brizantha (Hochst ex A. Rich) Stapf (cv. Marandu) grasses, with moderate stocking rate (DMS); degraded Urochloa (Brachiaria) decumbens pasture under extensive management (DP). The tropical pasture (Panicum sp.) in IHS was overseeded with oats (Avena bysantina Koch, cv. São Carlos) and ryegrass (Lolium multiflorum Lam., cv. BRS Ponteio) in the autumn. The intensively managed pastures (established in 2002) were divided into 12 paddocks (0.14 to 0.15 ha each) which were grazed for three days, under a rotational grazing system with 36 days of rest. Each DMS pasture (established in 1996) was divided into six paddocks (0.55 ha each) which were grazed for six days also under a rotational system (30 days rest). The degraded pastures (two paddocks of $1.7 \mathrm{ha}$ ) were kept under continuous grazing. Pastures were managed under variable stocking rate ("put and take") and stocking rates were adjusted accordingly to the visually estimated forage availability in each paddock. All pastures (except DP) were limed and fertilized with superphosphate and potassium chloride to achieve $20 \mathrm{mg} \mathrm{dm}^{-3}$ of $\mathrm{P}$ and $4 \%$
$\mathrm{K}$ in CTC - soil cation exchange capacity -, according to Oliveira et al. (2008). Annual top-dressing nitrogen fertilization was applied at the rate of $600 \mathrm{~kg} \mathrm{~N} \mathrm{ha}^{-1}$ in IHS, $400 \mathrm{~kg} \mathrm{~N} \mathrm{ha}^{-1}$ in DHS and $200 \mathrm{~kg} \mathrm{~N} \mathrm{ha}^{-1}$ in DMS. Doses were divided into five applications during the rainy season in DHS and DMS and eight applications, four during the wet and four during the dry season in IHS. The degraded pasture was not fertilized nor limed. Other relevant soil and management parameters are described in Table 1. The native forest soil was sampled so as to represent original soil conditions in the experimental areas. The IHS and DHS systems were implemented in 2002 and DP and DMS in 1996. Samples were collected in 2011 (Table 1).

Soil samples were collected at the following depths: $0-5,5-10,10-20,20-30,30-40,40-60,60-80$ and 80-100 cm, with six field replicates (three replicates per block). In each replicate, two sub-samples were collected on two sides of the trench, for each depth interval, using an aluminum ring of known volume, for subsequent evaluation of dry soil weight (at $110^{\circ} \mathrm{C}$ ) and determination of soil bulk density using the mean of two sub-samples.

\section{Soil sample preparation and carbon stocks determination}

Soil samples were air-dried at approximately 25 ${ }^{\circ} \mathrm{C}$ (until reaching constant mass), gently crushed using a mortar and pestle and passed through a 9-mesh sieve (particle size smaller than $2 \mathrm{~mm}$ ). Sub-samples were finely ground so as to be able to pass through a 100mesh sieve (particle size smaller than $0.150 \mathrm{~mm}$ ) for all analyses. Total $\mathrm{C}$ analysis was performed, in duplicate, on approximately $10 \mathrm{mg}$ of soil using a CHN elemental analyzer. Soil C stocks are usually estimated using the soil bulk density at each depth interval and the corresponding C content (Veldkamp, 1994). Subsequently, C stock data were corrected for soil compaction, according to the equation proposed by Sisti et al. (2004), using data from the soil under the natural vegetation as the reference. The calculation of the equivalent soil mass was carried out for the 0-30 and 0-100 cm layers according to Ellert and Bettany (1995), also using the native forest soil as the reference.

Table 1 - Management and soil characteristics of pastures under different levels of intensification in four beef cattle grazing systems and the native vegetation.

\begin{tabular}{|c|c|c|c|c|c|}
\hline Characteristic & $\mathrm{IHS}$ & DHS & DMS & DP & FO \\
\hline Stocking rate $\left(\mathrm{AU} \mathrm{ha}^{-1 *}\right)$ & 5.9 & 4.9 & 3.4 & 1.1 & - \\
\hline Management time (years) & 9 & 9 & 15 & 15 & - \\
\hline Sand $\left(\mathrm{g} \mathrm{kg}^{-1}\right)$ & 676 & 434 & 322 & 768 & 568 \\
\hline Silt $\left(\mathrm{g} \mathrm{kg}^{-1}\right)$ & 74 & 131 & 145 & 70 & 83 \\
\hline Clay $\left(\mathrm{g} \mathrm{kg}^{-1}\right)$ & 251 & 434 & 533 & 162 & 349 \\
\hline Soil texture class** & Sandy clay loam & Sandy clay & Clay & Sandy Loam & Sandy Clay loam \\
\hline
\end{tabular}




\section{Humification of Soil Organic Matter}

The analysis of SOM humification by Laser-Induced Fluorescence Spectroscopy (LIFS) is important because it complements soil $\mathrm{C}$ stock data. The LIFS technique measures recalcitrant $C$, that can be a sensitive indicator of changes caused by land use and soil management (Milori et al., 2011; Segnini et al., 2013; Martins et al., 2015; Bordonal et al., 2017).

Homogenized soil samples (particle size smaller than $0.15 \mathrm{~mm})$ were pelletized $(1 \mathrm{~cm} \times 2 \mathrm{~mm}$ pellets of approximately $0.5 \mathrm{~g}$ ) and submitted to 8 tons of pressure before SOM humification analyses by LIFS. Samples were excited by a continuous wave (cw) laser, at a wavelength of $405 \mathrm{~nm}$ radiation, emitted by diode laser equipment (labassembled instrument) with a power source of approximately $200 \mathrm{~mW}$. Experimental procedures were conducted according to Segnini et al. (2010). The measurement range was from $475 \mathrm{~nm}$ to $800 \mathrm{~nm}$, the integration time $500 \mathrm{~ms}$, and the average and boxcar five and four, respectively, for all evaluations. Five spectra were obtained for each sample and the results presented here correspond to the means of five measurements and field replicates. The ratio of the area under the fluorescence emission bands and total organic $\mathrm{C}$ content $\left(\mathrm{g} \mathrm{kg}^{-1}\right)$ were defined as the SOM humification index $\left(\mathrm{H}_{\text {LIFS }}\right)$ (Milori et al., 2006).

\section{Statistical analysis}

Data were analyzed by the mixed procedure of SAS (Statistical Analysis System, version 9.2), after verifying the residue normality by the Shapiro-Wilk test (PROC UNIVARIATE). When normality was not obtained, logarithmic or square root transformation of data was necessary.

The model included the effects of five treatments, eight soil sampling depths and the interaction between treatments and depth. The choice of the matrix that best fit the data was based on the lower corrected Akaike information criteria value (AICC) (Wang and Goonewardene, 2004). The effects of treatment were analyzed by Tukey test $(p \leq 0.05)$.

\section{Results and Discussion}

\section{Soil bulk density and SOM}

Soil layers $(p \leq 0.05)$ and pasture systems $(p \leq$ 0.01) affected soil bulk densities. Soils in DHS and DMS presented bulk densities similar to the soil in the forest (Table 2). In IHS, higher soil compaction (Table 2) may have occurred due to the combination of two factors, frequent irrigation and possibly intense animal trampling. According to Silva et al. (2003), soil compression is greater in soils with high water content. In the DP system, with greater soil exposure and no irrigation, there was also increased compaction and higher bulk density (Table 2). In general, soil bulk density depends on the soil structure, water amount, soil texture, SOM, management, land use, soil compaction and cover vegetation type (Ramos et al., 2015). Generally, soils under native vegetation present lower densities, because, for the most part, there is no compaction of the nondisturbed soil (Table 2). However, in this trial, soil bulk density in the forest was no different to the soils under the DHS and DMS systems. Pore size distribution and resistance to root penetration are among those physical properties that are altered by soil compaction.

According to Ramos et al. (2015), soil bulk density has a significant effect on root growth, but this depends on other factors such as water content in the soil. Despite the statistical difference observed, the variation in soil bulk density among the various soil profiles in this experiment was small (Table 2) and may be explained by root system growth in grassland systems (Silva et al., 2003). The presence of Panicum maximum and Brachiaria decumbens, which have abundant root systems, may have influenced soil structure in the pastures evaluated. Liming and fertilization also had an impact, causing an increase in forage and root yields, mostly in the second year after the recovery of the Brachiaria decumbens degraded pastures has been initiated (Oliveira et al., 2003).

Soil C content results indicate there was an interaction $(p \leq 0.05)$ between production system and soil depth. Higher soil C values were obtained in the surface layers, in all pasture systems and the forest, and $\mathrm{C}$ content decreased in the lower layers under all systems (Table 2, Figure 1). Superficial layers receive a continuous input of fresh material from vegetation and animals and this trend is commonly observed in most Brazilian soils, especially Oxisols (Sá et al., 2015). Similar results are observed in forests, mainly due to the deposition of decayed material from roots and vegetative aerial parts in the upper layers of the soil.

Table 2 - Soil bulk density (BD), carbon (C) content and organic matter (SOM) humification index $\left(\mathrm{H}_{\mathrm{LIFS}}\right.$ ) of pastures in four beef cattle grazing systems and the native vegetation.

\begin{tabular}{|c|c|c|c|c|c|c|c|c|c|c|c|c|c|c|}
\hline \multirow{2}{*}{ Item* } & \multicolumn{5}{|c|}{ Treatments (systems) } & \multicolumn{9}{|c|}{ Depths $(\mathrm{cm})$} \\
\hline & IHS & DHS & DMS & DP & FO & $0-5$ & $5-10$ & $10-20$ & $20-30$ & $30-40$ & $40-60$ & $60-80$ & $80-100$ & SEM \\
\hline $\mathrm{BD}\left(\mathrm{Mg} \mathrm{m}^{-3}\right)$ & $1.36^{\mathrm{a}}$ & $1.13^{b}$ & $1.09^{b}$ & $1.36^{\mathrm{a}}$ & $1.17^{\mathrm{b}}$ & $1.21^{\mathrm{bc}}$ & $1.25^{\mathrm{ab}}$ & $1.26^{\mathrm{a}}$ & $1.23^{\mathrm{bc}}$ & $1.22^{\mathrm{bc}}$ & $1.21^{\mathrm{bc}}$ & $1.19^{c}$ & $1.20^{\mathrm{bc}}$ & 0.0098 \\
\hline $\mathrm{C}\left(\%, \mathrm{~m} \mathrm{~m}^{-1}\right)$ & $1.09^{b}$ & $1.37^{a}$ & $1.50^{\mathrm{a}}$ & $0.95^{b}$ & $1.24^{\mathrm{ab}}$ & $2.04^{a}$ & $1.71^{b}$ & $1.40^{c}$ & $1.19^{d}$ & $1.03^{e}$ & $0.90^{f}$ & $0.81^{\mathrm{g}}$ & $0.73^{\mathrm{h}}$ & 0.035 \\
\hline $\mathrm{H}_{\mathrm{LFS}}$ (a.u.) $\times 10^{3}$ & $80.38^{b}$ & $30.54^{c}$ & $26.25^{c}$ & $107.1^{\mathrm{a}}$ & $58.78^{b}$ & $29.15^{\mathrm{g}}$ & $37.03^{f}$ & $45.60^{e}$ & $52.08^{d}$ & $62.58^{c}$ & $78.12^{b}$ & $87.54^{\mathrm{a}}$ & $92.76^{a}$ & 3.3172 \\
\hline
\end{tabular}

${ }^{*} \mathrm{BD}=$ Bulk density; $\mathrm{C}=$ soil carbon content; $\mathrm{H}_{\mathrm{LFS}}=$ soil organic matter humification index; IHS = Intensively managed irrigated Panicum maximum Jacques (cv. Tanzânia) pasture with high stocking rate; DHS = Intensively managed dry land Panicum maximum Jacques (cv. Tanzânia) pasture with high stocking rate; DMS = Dryland Urochloa (Brachiaria) decumbens pasture with moderate stocking rate; DP = Degraded Urochloa (Brachiaria) decumbens Stapf (cv. Basilisk) pasture under extensive management; FO = native vegetation ("seasonal semi-deciduous forest"); SEM = standard error of the means; Treat * Depth = Interaction pasture systems vs soil depth; ${ }^{\text {ah }}=$ means followed by different letters within a line are different $(p \leq 0.05)$ by the Tukey test. 
In soil layers above a depth of $10 \mathrm{~cm}$, soil $\mathrm{C}$ contents were higher in the dryland systems (DHS and DMS) compared to IHS and DP. Despite irrigation, soil C content in the $0-5 \mathrm{~cm}$ layer was lower in IHS compared to the forest. In layers between the depths of 10 and 30 $\mathrm{cm}$, soil $\mathrm{C}$ content was higher in DHS and DMS than in the forest, IHS and DP (Table 3, Figure 1). The soils in DHS and DMS, in addition to benefiting from good management, presented high clay content (Table 1). Consequently, they were able to accumulate considerable quantities of $\mathrm{C}$, well above the quantities detected under the native vegetation. These results corroborate findings by Fisher et al. (1994), who compared soils in well-managed pastures and savannas in South America. The authors showed the importance of tropical grasses in sequestering $\mathrm{C}$ in deeper soil layers.

Between the depths of 40 and $60 \mathrm{~cm}$, soil C content was higher in DMS, intermediate in IHS, DHS and the forest and lower in DP. In the other evaluated soil layers $(60-100 \mathrm{~cm}), \mathrm{C}$ content was similar for all systems (Table 3, Figure 1). These aspects indicate that pastures, after some years of management, show great potential

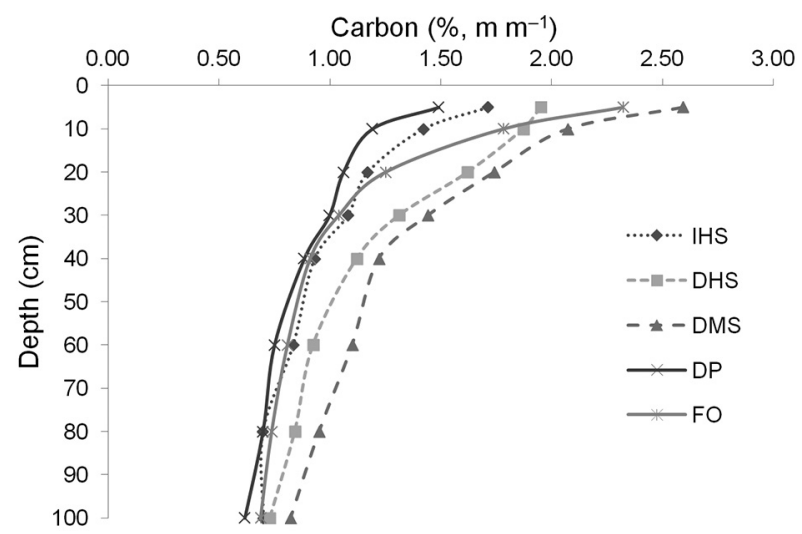

Figure 1 - Carbon content in the different layers of soil in the grazing systems and the native vegetation. $I H S=$ Intensively managed irrigated Megathyrsus (Panicum) maximum Jacques (cv. Tanzânia) pasture with high stocking rate; DHS = Intensively managed dry land Megathyrsus (Panicum) maximum Jacques (cv. Tanzânia) pasture with high stocking rate; DMS = Dryland Brachiaria decumbens pasture with moderate stocking rate; DP = Degraded Urochloa (Brachiaria) decumbens Stapf (cv. Basilisk) pasture under extensive management; $\mathrm{FO}=$ native vegetation ("seasonal semi-deciduous forest"). for removing $\mathrm{CO}_{2}$ from the atmosphere and enriching the soil with SOM, as indicated by Corazza et al. (1999).

\section{Soil C stocks}

Carbon stocks were corrected to an equal mass of soil at a depth of $100 \mathrm{~cm}$ under the native vegetation, in which $\mathrm{C}$ stock was $114.72 \mathrm{Mg} \mathrm{ha}^{-1}$. The $\mathrm{C}$ stocks for the first $30 \mathrm{~cm}$ layers were corrected to an equal mass of soil at a depth of $30 \mathrm{~cm}$ under the native vegetation in which C stock was $49.55 \mathrm{Mg} \mathrm{ha}^{-1}$ (Table 5).

On average, soils in DHS and DMS had the largest C stocks, compared with the other pasture systems and the native forest (Table 4). C stock content results indicate there was an interaction $(p \leq 0.05)$ between production system and soil depth (Table 4). Values of C stocks found in the $30 \mathrm{~cm}$ layer were $64 \%$ higher in DMS compared to the DP system and the other systems presented intermediary values (Table 5).

Considering all the layers $(0-100 \mathrm{~cm}), \mathrm{C}$ stock values ranged from $99.88 \mathrm{Mg} \mathrm{ha}^{-1}$ (in the degraded system) to $142.33 \mathrm{Mg} \mathrm{ha}^{-1}$ (in DMS), with higher values in DMS compared to DP, IHS and the forest and intermediate values in the DHS system (Table 5). In this trial, irrigation did not result in an increase in C stocks in the IHS system compared to the forest and the DMS system (Table 5).

According to De Bona et al. (2006), irrigation can increase soil $\mathrm{C}$ input but at times it is not enough to

Table 3 - Carbon (C) content in the different layers of soil in the grazing systems and the native vegetation.

\begin{tabular}{llllll}
\hline \multirow{2}{*}{ Depths } & \multicolumn{5}{c}{ Treatments } \\
\cline { 2 - 6 } & IHS & DHS & DMS & DP & FO \\
\hline $\mathrm{cm}$ & & \multicolumn{5}{c}{$\%, \mathrm{~m} \mathrm{~m}^{-1}$} \\
$0-5$ & $1.71^{\mathrm{bc}}$ & $1.95^{\mathrm{b}}$ & $2.59^{\mathrm{a}}$ & $1.49^{\mathrm{c}}$ & $2.32^{\mathrm{a}}$ \\
$5-10$ & $1.42^{\mathrm{b}}$ & $1.87^{\mathrm{a}}$ & $2.07^{\mathrm{a}}$ & $1.19^{\mathrm{b}}$ & $1.78^{\mathrm{ab}}$ \\
$10-20$ & $1.17^{\mathrm{b}}$ & $1.62^{\mathrm{a}}$ & $1.74^{\mathrm{a}}$ & $1.06^{\mathrm{b}}$ & $1.25^{\mathrm{b}}$ \\
$20-30$ & $1.08^{\mathrm{b}}$ & $1.31^{\mathrm{ab}}$ & $1.44^{\mathrm{a}}$ & $0.99^{\mathrm{b}}$ & $1.04^{\mathrm{b}}$ \\
$30-40$ & 0.93 & 1.12 & 1.22 & 0.88 & 0.91 \\
$40-60$ & $0.83^{\mathrm{ab}}$ & $0.92^{\mathrm{ab}}$ & $1.10^{\mathrm{a}}$ & $0.74^{\mathrm{b}}$ & $0.81^{\mathrm{ab}}$ \\
$60-80$ & 0.70 & 0.84 & 0.95 & 0.70 & 0.74 \\
$80-100$ & 0.70 & 0.73 & 0.82 & 0.62 & 0.69 \\
\hline
\end{tabular}

$\mathrm{HS}=$ Intensively managed irrigated Megathyrsus (Panicum) maximum Jacques (cv. Tanzânia) pasture with high stocking rate; DHS = Intensively managed dry land Megathyrsus (Panicum) maximum Jacques (cv. Tanzânia) pasture with high stocking rate; DMS = Dryland Brachiaria decumbens pasture with moderate stocking rate; DP = Degraded Urochloa (Brachiaria) decumbens Stapf (cv. Basilisk) pasture under extensive management; F0 = native vegetation ("seasonal semi-deciduous forest"); ${ }^{a-c}=$ means followed by different letters within a line are different $(p \leq 0.05)$ by the Tukey test.

Table 4 - Soil Carbon Stocks in the four beef cattle grazing systems and the native vegetation in two layers of soil $(0-30$ and 0-100 cm).

\begin{tabular}{|c|c|c|c|c|c|c|c|c|}
\hline \multirow{2}{*}{ Item } & \multicolumn{5}{|c|}{ Treatments } & \multicolumn{3}{|c|}{ Depths (cm) } \\
\hline & IHS & DHS & DMS & $\mathrm{DP}$ & FO & $0-30$ & $0-100$ & SEM \\
\hline Carbon Stocks (Mg ha-1) & $76.66^{b}$ & $94.87^{a}$ & $103.08^{a}$ & $68.85^{b}$ & $82.88^{b}$ & 50.68 & 119.85 & 5.08 \\
\hline
\end{tabular}


increase $\mathrm{C}$ stocks. Soil management may modify the irrigation effect on soil C stocks (Bayer et al., 2006). According to Andrén et al. (1992) an increase in soil water content caused by irrigation provides favorable conditions for microbial activity which intensify microbial organic matter (OM) decomposition and carbon mineralization. These factors may have contributed to the lower C stocks detected in IHS.

In this study the various pasture systems with $\mathrm{Bra}$ chiaria and Panicum presented soil C stocks similar or superior to stocks in the soil under the native forest. In the same context Braz et al. (2013) pointed out the potential of well-managed Brachiaria pastures for accumulating more soil $\mathrm{C}$ than degraded pastures.

The magnitude of $\mathrm{C}$ stocks found in this work (up to $142.33 \mathrm{Mg} \mathrm{ha}^{-1}$ ) was comparable to other results found in the literature, considering evaluations of grasslands in which samples were taken at the same soil profile depth $(100 \mathrm{~cm})$. Most of these evaluations had savanna as the natural vegetation. Fisher et al. (1994) found approximately $200 \mathrm{Mg} \mathrm{ha} \mathrm{h}^{-1}$ of $\mathrm{C}$ in the Colombian savannas, and above $200 \mathrm{Mg} \mathrm{ha}^{-1}$ when Brachiaria humidicola was introduced. Corazza et al. (1999) found $150 \mathrm{Mg} \mathrm{C} \mathrm{ha-1}$ in Brachiaria decumbens pasture in the Brazilian savanna while Silva et al. (2004) found around 100 and $113 \mathrm{Mg} \mathrm{C} \mathrm{ha}^{-1}$ in a degraded pasture with native grass and a Panicum maximum pasture, respectively. Fisher et al. (2007) reported C stocks in the order of 165 and $138 \mathrm{Mg} \mathrm{ha}^{-1}$ for productive and degraded pastures, respectively, in soils with $80 \%$ clay.

It is expected that the significant changes in $\mathrm{C}$ stocks occur in the $0-30 \mathrm{~cm}$ layer, as a result of agricultural management and changes in land use. The IPCC (Intergovernmental Panel on Climate Change) recommends that $\mathrm{C}$ stocks be evaluated in deep soil layers (down to $1 \mathrm{~m}$ ) when studying the ecosystem or effects of soil management on tropical pastures in which grasses present deep root systems (Batjes, 2010). According to Boddey et al. (2010), in most studies on soil C, stock assessments were made in the surface soil layers.

The interesting aspect of the results of this trial were the different contributions of different soil layers to total $\mathrm{C}$ stock. Considering all pasture systems and the

Table $\mathbf{5}$ - Carbon stocks in two layers of soil in the grazing systems and the native vegetation.

\begin{tabular}{|c|c|c|c|c|c|}
\hline \multirow{2}{*}{ Depths } & \multicolumn{5}{|c|}{ Treatments } \\
\hline & IHS & DHS & DMS & DP & FO \\
\hline $\mathrm{cm}$ & \multicolumn{5}{|c|}{ Mg ha-1 } \\
\hline $0-30$ & $44.59^{\mathrm{ab}}$ & $53.79^{\mathrm{ab}}$ & $63.7^{a}$ & $38.94^{b}$ & $49.55^{\mathrm{ab}}$ \\
\hline $0-100$ & $109.86^{b}$ & $129.63^{\mathrm{ab}}$ & $142.33^{a}$ & $99.88^{b}$ & $114.72^{b}$ \\
\hline \multicolumn{6}{|c|}{$\begin{array}{l}\text { IHS = Intensively managed irrigated Megathyrsus (Panicum) maximum } \\
\text { Jacques (cv. Tanzânia) pasture with high stocking rate; DHS = Intensively } \\
\text { managed dry land Megathyrsus (Panicum) maximum Jacques (cv. Tanzânia) } \\
\text { pasture with high stocking rate; DMS = Dryland Brachiaria decumbens } \\
\text { pasture with moderate stocking rate; DP = Degraded Urochloa (Brachiaria) } \\
\text { decumbens Stapf extensive management; FO = native vegetation ("seasonal } \\
\text { semi-deciduous forest"); }{ }^{\text {ab }}=\text { means followed by different letters within a line } \\
\text { are different ( } p \leq 0.05 \text { ) by the Tukey test. }\end{array}$} \\
\hline
\end{tabular}

forest, C stocks calculated for the $0-30$ and $30-100 \mathrm{~cm}$ layers represented, respectively, an average of $42 \%$ and $58 \%$ of the C stocks obtained for the $0-100 \mathrm{~cm}$ layers (Table 4 and 5). This emphasizes the sampling of deep soil layers, especially when studding pastures established with grasses possessing abundant root systems such as Brachiaria. Under productive pastures, considerable quantities of $\mathrm{C}$ can be stored as deep as $100 \mathrm{~cm}$ (Silva et al., 2004; Fisher et al., 2007). According to Schmidt et al. (2011), deeper soil layers also contribute to more than half of the global soil C stocks. This study shows the contribution of the root system of Brachiaria to increasing C stocks. But according to Fisher et al. (2007), total C stocks can decline over time, mainly if the area is not well managed or fertilized.

\section{Soil organic matter humification}

Lower $\mathrm{H}_{\text {LIFS }}$ were obtained for the surface layers of all evaluated soils (Table 2). The $\mathrm{H}_{\text {LIFS }}$ was higher for the soil under the degraded pasture, lower in DHS and DMS and intermediate in soils under the Forest and IHS, with statistical differences in interaction $(p \leq 0.01)$ levels varying accordingly to the layer depth (Table 2 and 6; Figure 2). The $\mathrm{H}_{\text {LIFS }}$ of DHS and DMS were lower compared to the other pastures and were similar to the native forest index for the surface layers (Table 6). In the deep layers, differences between $\mathrm{H}_{\text {LIFS }}$ were greater with lower values in DHS and DMS compared to IHS, DP and the forest (Table 6; Figure 2).

The lower $\mathrm{H}_{\text {LIFS }}$ obtained for the top soil layers in the pastures can be associated with the occurrence of labile $\mathrm{C}$ derived from a continuous supply of fresh ma-

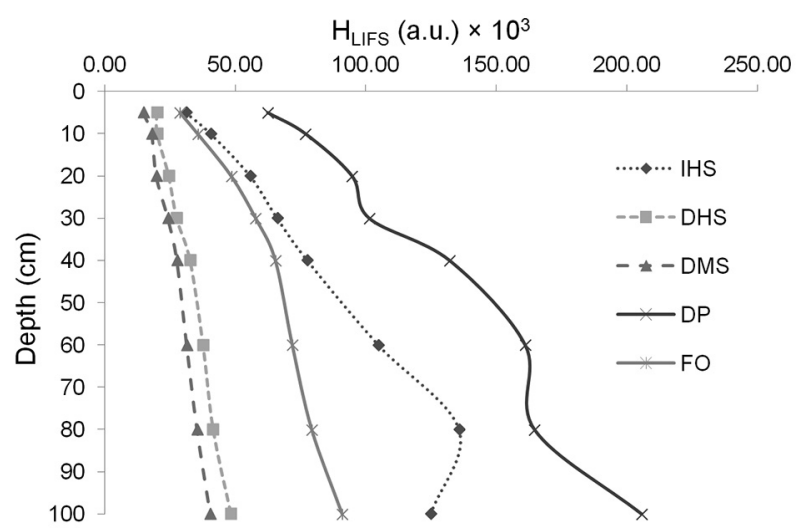

Figure 2 - Humification index $\mathrm{H}_{\mathrm{LFS}}$ in the different layers of soil in the grazing systems and the native vegetation. IHS = Intensively managed irrigated Megathyrsus (Panicum) maximum Jacques (cv. Tanzânia) pasture with high stocking rate; DHS = Intensively managed dry land Megathyrsus (Panicum) maximum Jacques (cv. Tanzânia) pasture with high stocking rate; DMS = Dryland Brachiaria decumbens pasture with moderate stocking rate; DP = Degraded Urochloa (Brachiaria) decumbens Stapf extensive management; FO = native vegetation ("seasonal semi-deciduous forest"). 
Table 6 - Humification index $\mathrm{H}_{\mathrm{LIFS}}$ in the different layers of soil in the grazing systems and the native vegetation.



$\mathrm{HHS}=$ Intensively managed irrigated Megathyrsus (Panicum) maximum Jacques (cv. Tanzânia) pasture with high stocking rate; DHS = Intensively managed dry land Megathyrsus (Panicum) maximum Jacques (cv. Tanzânia) pasture with high stocking rate; DMS $=$ Dryland Brachiaria decumbens pasture with moderate stocking rate; DP $=$ Degraded Urochloa (Brachiaria) decumbens Stapf extensive management; FO = native vegetation ("seasonal semi-deciduous forest"); ${ }^{a \cdot d}=$ means followed by different letters within a line are different $(p \leq 0.05)$ by the Tukey test.

terial from the cover vegetation and animals. In deeper layers there is an increase in $\mathrm{H}_{\text {LIFS }}$ due to the presence of more recalcitrant $\mathrm{C}$ provided by unsaturated organic compounds containing double bonds and condensed rings. Greater humification increases soil resistance against microbial decomposition and, consequently, enhances SOM stability (Segnini et al., 2010). The aromatic structures present in rigid molecules of humified SOM are considered to be more recalcitrant or stable in terms of biological decomposition than structures derived from polysaccharides and proteinaceous moieties (Bayer et al., 2006). Results presented here are in agreement with previous studies by Milori et al. $(2006,2011)$ and Tivet et al. (2013). Considering the humification in DP, it is important to emphasize that the lower levels of $\mathrm{C}$ and the high humification index obtained may indicate that at the degradation stage the rigid and condensed aromatic structures presented in SOM are predominant since there is no effective microbial activity to metabolize additional material. Morover, there is no labile $\mathrm{C}$ input into the system, already degraded.

The analyses of SOM humification complements soil $\mathrm{C}$ stock data because the LIFS technique measures recalcitrant $\mathrm{C}$ which can be a sensitive indicator of variances, caused by changes in land use and soil management, in terms of mitigation of $\mathrm{CO}_{2}$ emissions (Milori et al., 2011). The "vulnerability" of $\mathrm{C}$ was checked in this kind of assessment. Considering the results of this study, it is possible to infer that the DHS and DMS systems that had the highest $\mathrm{C}$ stock values are susceptible to $\mathrm{CO}_{2}$ losses if management is not appropriate which is mainly due to the high lability of $\mathrm{C}$ in their soils particularly in the surface layers. In studies of soil quality $\mathrm{C}$ stock levels per se are not always a sensitive indicator of variances caused by changes in land use and soil management, the $\mathrm{C}$ labile fraction being more affected and more sensitive compared to recalcitrant $\mathrm{C}$ fractions.
According to Ontl and Schulte (2012), effects of land management on soil organic $\mathrm{C}$ levels, especially the impacts of management in agricultural settings, is the subject of much of the current research. According to these authors, the main changes in soil $\mathrm{C}$ take a relatively long time to occur making punctual and short period measurements of changes in $\mathrm{C}$ stocks less than meaningful.

\section{Conclusions}

The results from this study indicate the capacity of tropical pastures to mitigate GHG emissions in livestock production systems, when under intensive management. In this case, soils under tropical pastures may act as long-term $\mathrm{C}$ sinks and most of the $\mathrm{C}$ is stored below $30 \mathrm{~cm}$ deep soil layers.

Carbon stock and humification indexes are useful tools for diagnosing degradation in pastures. Low $\mathrm{C}$ stocks associated with high humification indexes are characteristics of degraded pastures in which significant amounts of organic matter have been lost. Pasture systems with high soil $\mathrm{C}$ stocks and low humification indexes are fragile and susceptible to $\mathrm{CO}_{2}$ losses to the atmosphere if management is not correct due to the high lability of soil $\mathrm{C}$.

It is necessary to develop technologies to improve C sequestration in irrigated pastures. Definition of a balance between water supply and mineralization of organic matter will avoid excessive mineralization and preserve any increase in the soil $\mathrm{C}$ stock.

\section{Acknowledgments}

To Fundação de Amparo à Pesquisa do Estado de São Paulo - FAPESP (project: 2010/09211-6); the Conselho Nacional de Desenvolvimento Científico e Tecnológico - CNPq (project 562861-2010); Coordenação de Aperfeiçoamento de Pessoal de Nivel Superior - CAPES and Embrapa for financially supporting the PECUS (Sustainable Livestock) Research Network.

\section{Authors' Contributions}

Conceptualization: Segnini, A., Xavier, A.A.P., Oliveira, P.P.A., Pedroso, A.F., Milori, D.M.B.P. Data acquisition: Segnini, A., Xavier, A.A.P., OtavianiJunior, P.L., Oliveira, P.P.A., Pedroso, A.F. Data Analysis: Segnini, A., Xavier, A.A.P., Otaviani-Junior, P.L., Oliveira, P.P.A., Pedroso, A.F., Praes, M.F.F.M., Rodrigues, P.H.M., Milori, D.M.B.P. Design of methodology: Segnini, A., Xavier, A.A.P., Otaviani-Junior, P.L., Oliveira, P.P.A., Pedroso, A.F., Praes, M.F.F.M., Rodrigues, P.H.M., Milori, D.M.B.P. Writing and Editing: Segnini, A., Xavier, A.A.P., Oliveira, P.P.A., Pedroso, A.F., Praes, M.F.F.M., Rodrigues, P.H.M., Milori, D.M.B.P. 


\section{References}

Andrén, O.; Steen, E.; Rajkai, K. 1992. Modelling the effects of moisture on barley straw and root decomposition in the field. Soil Biology and Biochemistry 24: 727-736.

Assad, E.D.; Pinto, H.S.; Martins, S.C.; Groppo, J.D.; Salgado, P.R.; Evangelista, B.; Vasconcellos, E.; Sano, E.E.; Pavão, E.; Luna, R.; Camargo, P.B.; Martinelli, L.A. 2013. Changes in soil carbon stocks in Brazil due to land use: paired site comparisons and a regional pasture soil survey. Biogeosciences 10: 6141-6160.

Batjes, N.H. 2010. A Global Framework of Soil Organic Carbon Stocks under Native Vegetation for Use with the Sample Assessment Option of the Carbon Benefits Project System: report 2010. VBP/ISRIC, Wageningen, The Netherlands. Available at: https://library.wur.nl/isric/fulltext/isricu_ t4dcbe7f0_001.pdf [Accessed Oct 25, 2017]

Bayer, C.; Martin-Neto, L.; Mielniczuk, J.; Dieckow, J.; Amado, T.J.C. 2006. $\mathrm{C}$ and $\mathrm{N}$ stocks and the role of molecular recalcitrance and organomineral interaction in stabilizing soil organic matter in a subtropical Acrisol managed under no-tillage. Geoderma 133: 258-268.

Boddey, R.M.; Jantalia, C.P.; Macedo, M.O.; Oliveira, O.C.; Resende, A.S.; Alves, B.J.R.; Urquiaga, S. 2006. Potential of carbon sequestration in soils of the Atlantic forest region of Brazil. p. 305-347. In: Lal, R.; Cerri, C.C.; Bernoux, M.; Etchervers, J.; Cerri, E., eds. Carbon sequestration in soils of Latin America. CRC Press, Boca Raton, FL, USA.

Boddey, R.M.; Jantalia, C.P.; Conceição, P.C.; Zanatta, J.A.; Bayer, C.; Mielniczuk, J.; Dieckow, J.; Santos, H.P.; Denardin, J.E.; Aita, C.; Giacomini, S.J.; Alves, B.J.R.; Urquiaga, S. 2010. Carbon accumulation at depth in Ferralsols under zero-till subtropical agriculture. Global Change Biology 16: 784-795.

Bordonal, R.O.; Lal, R.; Ronquim, C.C.; Figueiredo, E.B.; Carvalho, J.L.N.; Maldonado Jr., W.; Milori, D.M.B.P.; La Scala Jr., N. 2017. Changes in quantity and quality of soil carbon due to the land-use conversion to sugarcane (Saccharum officinarum) plantation in southern Brazil. Agriculture, Ecosystems and Environment 240: 54-65.

Braz, S.P.; Urquiaga, S.; Alves, B.J.R.; Jantalia, C.P.; Guimarães, A.P.; Santos, C.A.; Santos, S.C.; Pinheiro, E.F.M.; Boddey, R.M. 2013. Soil carbon stocks under productive and degraded Brachiaria pastures in the Brazilian Cerrado. Soil Science Society of America Journal 77: 914-928.

Bustamante, M.M.C.; Nobre, C.A.; Smeraldi, R.; Aguiar, A.P.D.; Barioni, L.G.; Ferreira, L.G.; Longo, K.; May, P.F.; Ometto, J.P.H.B. 2012. Estimating greenhouse gas emissions from cattle raising in Brazil. Climate Change 115: 559-577.

Conant, R.T.; Paustian, K.; Elliott, E.T. 2001. Grassland management and conversion into grassland: effects on soil carbon. Applied Ecology 11: 343-355.

Corazza, E.J.; Silva, J.E.; Resck, D.V.; Gomes A.C. 1999. Behavior of different management systems as a source or sink of $\mathrm{C}-\mathrm{CO}_{2}$ in relation to Cerrado type vegetation. Revista Brasileira de Ciência do Solo 23: 425-432 (in Portuguese, with abstract in English).
De Bona, F.D.; Bayer, C.; Bergamaschi, H.; Dieckow, J. 2006. Soil organic carbon in sprinkler irrigation systems under no-till and conventional tillage. Revista Brasileira de Ciência do Solo 30: 911-920 (in Portuguese, with abstract in English).

Ellert, B.H.; Bettany, J.R. 1995. Calculation of organic matter and nutrients stored in soils under contrasting management regimes. Canadian Journal of Soil Science 75: 529-538.

Fisher, M.J.; Rao, I.M.; Ayarza, M.A.; Lascano, C.E.; Sanz, J.I.; Thomas, R.J.; Vera, R.R. 1994. Carbon storage by introduced deep-rooted grasses in the South American savannas. Nature 371: 236-238.

Fisher, M.J.; Braz, S.P.; Santos, R.S.M.; Urquiaga, S.; Alves, B.J.R.; Boddey, R.M. 2007. Another dimension to grazing systems: soil carbon. Tropical Grasslands 41: 65-83.

Martins, B.H.; Araujo-Junior, C.F.; Miyazawa, M.; Vieira, K.M.; Milori, D.M.B.P. 2015. Soil organic matter quality and weed diversity in coffee plantation area submitted to weed control and cover crops management. Soil and Tillage Research 153: 169-174.

Milori, D.M.P.B.; Galeti, H.V.A.; Martin-Neto, L.; Diekow, J.; González-Peréz, M.; Bayer, C.; Salton, J. 2006. Organic matter study of whole soil samples using laser-induced fluorescence spectroscopy. Soil Science Society of America Journal 70: 57-63.

Milori, D.M.P.B.; Segnini, A.; Silva, W.T.L.; Posadas, A.; Mares, V.; Quiroz, R.; Martin-Neto, L. 2011. Emerging techniques for soil carbon measurements. p. 252-262. In: Wollenberg, E.; Nihart, A.; Tapio-Biström, M.L.; Grieg-Gran, M., eds. Climate Change, Mitigation and Agriculture. CGIAR Research Program on Climate Change, Agriculture and Food Security, London, UK.

Nepstad, D.; Soares-Filho, B.S.; Merry, F.; Lima, A.; Moutinho, P.; Carter, J.; Bowman, M.; Cattaneo, A.; Rodrigues, H.; Schwartzman, S.; McGrath, D.G.; Stickler, C.M.; Lubowski, R.; Piris-Cabezas, P.; Rivero, S.; Alencar, A.; Almeida, O.; Stella, O. 2009. The end of deforestation in the Brazilian Amazon. Science 326: 1350-1351.

Oliveira, P.P.A.; Boaretto, A.E.; Trivelin, P.C.O.; Oliveira, W.S.; Corsi, M. 2003. Liming and fertilization for restoring degraded Brachiaria decumbens pasture on sandy soil. Scientia Agricola 60: $125-131$.

Oliveira, P.P.A.; Corsi, M. 2005. Degraded pasture recovery for intensive cattle production systems $=$ Recuperação de pastagens degradadas para sistemas intensivos de produção de bovinos. Embrapa Pecuária Sudeste, São Carlos, SP, Brazil. (Circular Técnica, 38). Available at https://ainfo.cnptia. embrapa.br/digital/bitstream/CPPSE/15659/1/Circular38.pdf [Accessed Aug 3, 2017] (in Portuguese).

Oliveira, P.P.A.; Penati, M.A.; Corsi, M. 2008. Soil correction and pasture fertilization in intensive milk production systems = Correção do solo e fertilização de pastagens em sistemas intensivos de produção de leite. Embrapa Pecuária Sudeste, São Carlos, SP, Brazil. (Documento, 86). Available at: http:// ainfo.cnptia.embrapa.br/digital/bitstream/item/37957/1/ Documentos86.pdf [Accessed Aug 3, 2017] (in Portuguese).

Oliveira, S.G.; Berchielli, T.T.; Pedreira, M.S.; Primavesi, O.; Frighetto, R.; Lima, M.A. 2007a. Effect of tannin levels in sorghum silage and concentrate supplementation on apparent digestibility and methane emission in beef cattle. Animal Feed Science and Technology 135: 236-248. 
Oliveira, P.P.A.; Trivelin, P.C.O.; Oliveira, W.S. 2007b. Urea ${ }^{15} \mathrm{~N}$ balance in the fractions of a Brachiaria brizantha cv. Marandu pasture under recovery with different liming dates. Revista Brasileira de Zootecnia 36: 1982-1989 (in Portuguese, with abstract in English).

Ontl, T.A.; Schulte, L.A. 2012. Soil carbon storage. Nature Education Knowledge 3: 35.

Ramos, M.R.; Favaretto, N.; Uhlmann, A.; Dieckow, J.; Vezzani, F.; Almeida, L.D. 2015. Vegetable production under the organic system: effects on soil physical attributes. Amazonian Journal of Agricultural and Environmental Sciences 58: 45-51 (in Portuguese, with abstract in English).

Ruviaro, C.F.; De Léis, C.M.; Lampert, V.D.N.; Barcellos, J.O.J.; Dewes, H. 2014. Carbon footprint in different beef production systems on a southern Brazilian farm: a case study. Journal of Cleaner Production 96: 435-443.

Sá, J.C.D.M.; Séguy, L.; Tivet, F.; Lal, R.; Bouzinac, S.; Borszowskei, P.R.; Briedis, C.; Santos, J.B.D.; Hartman, D.D.C.; Bertoloni, C.G.; Rosa, J.; Friedrich, T. 2015. Carbon depletion by plowing and its restoration by no-till cropping systems in Oxisols of subtropical and tropical agro-ecoregions in Brazil. Land Degradation \& Development 26: 531-543.

Santos, P.M.; Corrêa, L.A. 2005. Management of tropical pastures = Manejo de pastagens tropicais. Embrapa Pecuária Sudeste, São Carlos, SP, Brazil. (Documentos, 46) Available at: http://www.cppse.embrapa.br/sites/default/files/principal/ publicacao/Documentos46.pdf [Accessed Oct 24, 2017] (in Portuguese).

Schmidt, M.W.I.; Torn, M.S.; M.S.; Abiven, S.; Dittmar, T.; Guggenberger, G.; Janssens, I.A.; Kleber, M.; Kogel-Kbner, I.; Lehmann, J.; Manning, D.A.C.; Nannipieri, P.; Rasse, D.P.; Weiner, S.; Trumbore, S.E. 2011. Persistence of soil organic matter as an ecosystem property. Nature 478: 49-56.
Segnini, A.; Posadas, A.; Quiroz, R.; Milori, D.M.B.P.; Saab, S.C.; Vaz, C.M.P.; Martin-Neto, L. 2010. Spectroscopic assessment of soil organic matter in wetlands from the high Andes. Soil Science Society of America Journal 74: 2246-2253.

Segnini, A.; Carvalho, J.L.N.; Bolonhezi, D.; Milori, D.M.B.P.; Silva, W.T.L.; Simões, M.L.; Cantarella, H.; Maria, I.C.; MartinNeto, L. 2013. Carbon stock and humification index of organic matter affected by sugarcane straw and soil management. Scientia Agricola 70: 321-326.

Silva, A.P.; Imhoff, S.; Corsi, M. 2003. Evaluation of soil compaction in an irrigated short-duration grazing system. Soil and Tillage Research 70: 83-90.

Silva, J.E.; Resck, D.V.S.; Corazza, E.J.; Vivaldi, L. 2004. Carbon storage in clayey Oxisol cultivated pastures in the "Cerrado" region, Brazil. Agriculture, Ecosystems and Environment 103: 357-363.

Sisti, C.P.J.; Santos, H.P.; Kohhann, R.; Alves, B.J.R.; Urquiaga, S.; Boddey, R.M. 2004. Change in carbon and nitrogen stocks in soil under 13 years of conventional or zero tillage in southern Brazil. Soil \& Tillage Research 76: 39-58.

Tivet, F.; Moraes, S.J.C.; Lal, R.; Milori, D.M.B.P.; Briedis, C.; Letourmy, P.; Pinheiro, L.A.; Borszowskei, P.R.; Cruz, H.D. 2013. Assessing humification and organic $C$ compounds by laser-induced fluorescence and FTIR spectroscopies under conventional and no-till management in Brazilian Oxisols. Geoderma 207-208: 71-81.

Veldkamp, E. 1994. Organic-carbon turnover in three tropical soils under pasture after deforestation. Soil Science Society of America Journal 58: 175-180.

Wang, L.A.; Goonewardene, Z. 2004. The use of mixed models in the analysis of animal experiments with repeated measures data. Canadian Journal of Animal Science 84: 1-11. 